\title{
A new species of Acroleptus Bourgeois (Coleoptera: Lycidae) from the Brazilian Amazonian rainforest, with a note on its homonymy with Acroleptus Cabanis (Aves)
}

\section{Author: Vinicius S. Ferreira}

This is a postprint of an article that originally appeared in Zootaxa on April 25, 2015 and the final version can be found here https://doi.org/10.11646/zootaxa.3949.2.10

Ferreira, Vinicius S. (2015). A new species of Acroleptus Bourgeois (Coleoptera: Lycidae) from the Brazilian Amazonian rainforest, with a note on its homonymy with Acroleptus Cabanis (Aves). Zootaxa, 3949(2), 297-300. doi:10.11646/zootaxa.3949.2.10 


\title{
A new species of Acroleptus Bourgeois (Coleoptera: Lycidae) from the Brazilian Amazonian rainforest, with a note on its homonymy with Acroleptus Cabanis (Aves)
}

\author{
VINICIUS S. FERREIRA
}

Museu de Zoologia da Universidade de São Paulo (MZSP), Setor de Entomologia, Laboratório de Sistemática, Evolução e Bionomia de Coleoptera, Avenida Nazaré, 481, Ipiranga, CEP: 04263-000 São Paulo-SP, Brazil. E-mail: vinicius.sfb@gmail.com

\begin{abstract}
Acroleptus costae sp. nov. is described from the Brazilian Amazonian rainforest, raising the diversity of the formerly monotypic genus to two known species. The validity of Acroleptus Bourgeois, 1886 (Insecta) is maintained while Acroleptus Cabanis, 1861 (Aves) is considered to be an incorrect subsequent spelling.
\end{abstract}

Key words: taxonomy, Lycinae, Calopterini, Neotropical Region, Amazonian forest

\section{Resumo}

Acroleptus costae sp. nov. é descrito para a Floresta Amazônica Brasileira, elevando a diversidade do anteriormente monotípico gênero para duas espécies conhecidas. A validade de Acroleptus Bourgeois, 1886 (Insecta) é mantida enquanto que Acroleptus Cabanis, 1861 (Aves) é considerado uma grafia subsequente incorreta.

Palavras-chave: Taxonomia, Lycinae, Calopterini, Região Neotropical, Floresta Amazônica

\section{Introduction}

The monotypic genus Acroleptus Bourgeois, 1886, belongs to the subtribe Acroleptina of the Calopterini. It is closely related to Lycomorphon Pic, 1922, Lycinella Gorham, 1884 and Ceratopriomorphus Pic, 1922 (Bocakova 2005). The genus was redescribed and treated in a phylogenetic analysis of the tribe by Bocakova (2003, 2005). Acroleptus chevrolati Bourgeois, 1886 is a rare species and since its description has only been mentioned in two catalogues (Kleine 1933; Blackwelder 1945).

Acroleptus can be easily distinguished from other Calopterini by the flabellate antennae, with branches 2-3 times longer than the stem of antennnomere and by the median longitudinal carinae on the pronotum weakened (Bocakova 2003). While examining material from Instituto Nacional de Pesquisas da Amazônia (INPA) a single specimen of a new species of Acroleptus Bourgeois, 1886 was found. I take this opportunity to describe this species and thereby widen the concept of the genus.

The genus Acroleptus Bourgeois, 1886 (Insecta) is not threatened by the fact that Cabanis (1861: 90) wrote a footnote stating that Acroleptus would be the grammatically correct spelling of Acroleptes Bonaparte, 1854 (Aves). However, previously on the same page, Cabanis correctly used Bonaparte's spelling with the description of a species that validated Acroleptes. Subsequently, no one, not even Cabanis $(1861,1865)$ ever used the spelling Acroleptus as a valid binomen, for a bird or other animal. In spite of the incorrect Acroleptus being listed in various catalogs (Gray 1870:78, McGregor 1920:8, Hellmayr 1936: 14), Acroleptus Cabanis is invalid and should be treated as a misspelling. Modern electronic searches will return the name Acroleptus Cabanis, 1861, but this is a continuation of a misspelling and does not endanger Acroleptus Bourgeois, 1886. 


\section{Material and methods}

The specimen was relaxed in hot water and detergent under a stereomicroscope. Drawings were prepared from photographs taken with a Leica M205C®equipped with a Leica DFC 295 camera. Photographs of genitalia were taken usinga SEM Zeiss LEO 440 camera and a Zeiss Microscope Axionskop 2.The image layers were aligned using Zerene Stacker version 1.04. The drawings and photographs were edited in Adobe Photoshop CS6 and Adobe Illustrator CS5.

\section{Results}

\section{Acroleptus costae sp. nov.}

(Figs. 1-4)

Diagnosis. Acroleptus costae can be separated from A. chevrolati by its small eyes, the slender longitudinal carina on the pronotum which lacks an longitudinal areola, the pronotum widest anteriorly, the absence of spines on the apex of the parameres, and by the rounded apical margin of the phallobase, with lateral margins almost parallel.

Description. General coloration yellow, apical half of elytra black. Antennomeres I-III and XI yellow, as well as flabellum of antennomeres IX and X, IV-X segments black.

Head longer than wide, hypognathous, with interocular distance twice as longer as eye diameter; mouthparts reduced, mandibles arcuate, connate with labrum. Antennae pubescent, inserted in projection of frons (Fig. 1); antennomeres I-II simple, I subconic, II small (1/4 the length of I); antennomeres III-XI flabellate, reaching distal 1/4 of elytra (Fig. 2); III slightly shorter than I, flabellum subequal in length to the stem; stem IV subequal in length to III, with flabellum slightly longer than stem; stem of IV to X gradually increasing in length, with each flabellum longer than respective stem.

Pronotum trapezoidal, transverse, with anterior angles distinct, acute; median longitudinal carina weak (Fig. 1). Scutellum forked behind, short, with both apices acute. Elytra posteriorly dehiscent, slender, 6.5 times longer than pronotum; each with 4 elytral costae, weakly reticulate at apex. Prosternum Y-shaped, reaching hypomeron; thoracicspiracle tubular, elongate. Mesoventrite trapezoidal, without longitudinal visible suture, fused to mesepisternum without apparent suture; with conspicuous row of setae on mesepimeron; thoracic-spiracle rounded, not produced. Metaventrite convex, anterior angles rounded, divergent posteriad, anteriorly very close to the posterior margin of mesoventrite; posterior angles truncate, divergent, discrimen complete (Fig. 3). Pro- and mesocoxae short; mesocoxae separated by anterior margin of mesoventrite; metacoxae widened; trochanters elongate; profemur and protibiae clavate, the later slender [other femora, tibiae and tarsi missing]. Male genitalia symmetrical; median lobe as long as phallobase, slightly broad in distal half, medially with inner margins folded; parameres less than half length of the median lobe; phallobase with apical margin rounded, lateral margins almost parallel-sided, median suture incomplete, present only in apical third (Fig. 4).

Length: $3.8 \mathrm{~mm}$. Width (across humerus): $1.0 \mathrm{~mm}$

Type material. Holotype, ổ: Brazil: Rondônia State, Porto Velho, BR: 364 -Km 48, 17-IX-1979, Jorge Arias col.; Malaise trap (INPA).

Etymology. Named in honor of Dr. Cleide Costa, the great Brazilian entomologist who dedicated her life to the study of neotropical insect larvae and studies of Elateroidea, and in commemoration of her 50 year career in the Museu de Zoologia da Universidade de São Paulo (MZSP).

\section{Acknowledgments}

I am very grateful to Cleide Costa (MZSP) for her support and help in the last years. To Antonio Santos-Silva (MZSP) and to Michael A. Ivie (Montana State University) for the support, help and discussions concerning the nomenclatural questions and general corrections in the manuscript. To Michael Geiser (Natural History Museum, London), Harald Schillhamer (Naturhistorisches Museum Wien, Vienna) and Hingrid Y. Quintino (MZSP) for helping with the German passages and translations of Cabanis's papers. To Lívia P. Prado, Felipe F. Barbosa (MZSP) and Simone P. Rosa (Universidade Federal de Itajubá) for the review of the manuscript; to Augusto H. Loureiro (INPA), for the loan of Lycidae to my research; and to Carlos R. F. Brandão (MZSP), for use of his photographic equipment. 

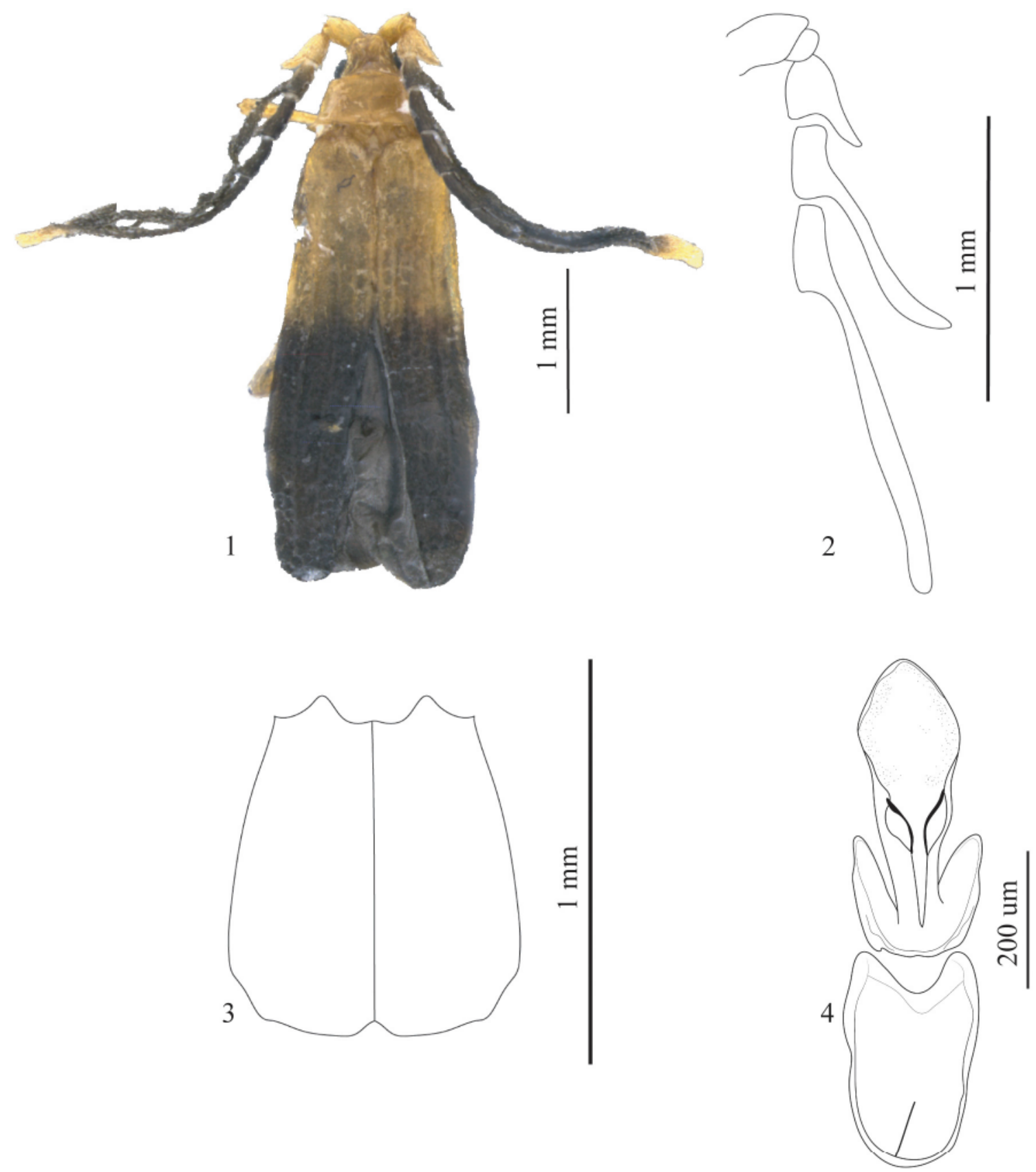

FIGURES 1-4. Acroleptus costae sp. n., holotype. 1. Dorsal view. 2. Antennomeres I-V. 3. Metaventrite. 4. Ventral view of male genitalia.

\section{References}

Bocakova, M. (2003) Revision of the tribe Calopterini (Coleoptera, Lycidae). Studies on Neotropical Fauna and Environment, 38 (3), 207-234.

Bocakova, M. (2005) Phylogeny and classification of the tribe Calopterini (Coleoptera, Lycidae). Insect Systematics and Evolution, 35 (4), 347-447.

Bonaparte, C.L. (1854) Notes sur les Collections rapportées en 1853, par M.A. Delattre, de son voyage en Californie et dans le Nicaragua. Septième Communication. Chanterus dentirostres. Comptes rendus hebdomadaires des séances de l'Académie des sciences, 38, 378-389.

Bourgeois, J. (1886) [Acroleptus chevrolati], Bulletin Entomologique. Annales de la Société entomologique de France, 6 (6), 68-71. 
Cabanis, J. (1861) Uebersicht der im Berliner Museum befindlichen Vögel von Costa Rica. Journal für Ornithologie, 50, $81-96$.

Cabanis, J. (1865) Ueber neue oder weniger bekannte exotische Vögel. Journal für Ornithologie, 78, 406-414.

Gray, G.R. (1870) Hand-list of genera and species of birds, distinguishing those contained in the British Museum. Part 2. Conirostres, Scansores, Columbae \& Gallinae. Trustees of the British Museum, London, $278 \mathrm{pp}$.

Hellmayr, C.E. (1936) Catalogue of birds of the Americas and the adjacent islands in Field Museum of Natural History, part IX, Tersinidae, Thraupidae. Field Museum of Natural History Publications, Zoological Series, 13, 1-458.

Kleine, R. (1933) Lycidae Pars 128. In: Junk, W. \& Schenkling, S. (Eds.), Coleopterorum Catalogus auspicii set auxilio. Berlin. pp. 3-145.

McGregor, R.C. (1920) Index to the genera of birds. Manila Bureau of Printing, $185 \mathrm{pp}$.

Neave, S.A. (Ed.) (2005) NomenclatorZoologicus. Vol. 1-10. A list of the names of genera and subgenera in zoology from the tenth edition of Linnaeus 1758 to the end of 2004. Version 0.86. Available from: http://uio.mbl.edu/ NomenclatorZoologicus (accessed 10 February 2015) 